\title{
Plasmonic nanoparticles and their characterization in physiological fluids
}

\author{
Dominic A. Urban a,1, Laura Rodriguez-Lorenzo ${ }^{\mathrm{a}, 1}$, Sandor Balog ${ }^{\mathrm{a}, 1}$, Calum Kinnear ${ }^{\mathrm{a}, 1}$, \\ Barbara Rothen-Rutishauser ${ }^{\mathrm{a}}$, Alke Petri-Fink ${ }^{\mathrm{a}, \mathrm{b}, *}$ \\ a Adolphe Merkle Insitute, University of Fribourg, Chemin des Verdiers 4, 1700 Fribourg, Switzerland \\ b Chemistry Department, University of Fribourg, Chemin du Musée 9, 1700 Fribourg, Switzerland
}

\begin{abstract}
Nanoparticles possess unique properties beyond that of classical materials, and while these properties can be used for designing a dedicated functionality, they may also pose a problem to living organisms, to human health and the environment. The specific primary routes by which nanoparticles may interact with the human body include inhalation, injection, ingestion and application to the skin. Independent of the entry route, the particles inevitably encounter a complex physiological fluid populated with e.g. proteins, vitamins, lipids and salts/ions. Different consequences of such an encounter may include formation of a surface-bound protein layer, particle dissolution or aggregation, which are expected to have a crucial impact on cellular interaction. Understanding cellular responses to nanoparticle interactions starts with understanding particle behavior in physiological fluids. Nanoparticles are now available in practically any size, shape and functionalization, to promote distinct optical, magnetic, and physico-chemical properties, making the prediction of their behavior, in physiological fluids, not a trivial task. Characterization has therefore become of paramount importance. In this review, we give an overview about the diversity of physiological fluids as well as present an inventory of the most relevant experimental techniques used to study plasmonic nanoparticles.
\end{abstract}

\section{Introduction}

The development of "nano" started over 20 years ago, with nanoscale science and technology now having an increasing impact on many aspects of our daily lives. The enormous potential and rapid expansion of nanotechnology has resulted in an exploding array of engineered nanomaterials, which are increasingly being used for commercial purposes [1] but with clear differentiation across industry sectors. Typically, materials applications are reaching the markets first, with electronics and IT applications following closely behind [2]. Nanobiotechnology and nanomedicine have the potential to revolutionize diagnostic tools and treatment strategies, which are more personalized, efficient, or easier to administer. However, healthcare and life sciences applications have the longest time-to-market: approval by the regulatory agencies, technological adjustments in manufacturing [3], and potential risks associated

\footnotetext{
* Corresponding author at: Adolphe Merkle Insitute, University of Fribourg, Chemin des Verdiers 4, 1700 Fribourg, Switzerland. Tel.: +41 263009501..

E-mail address: alke.fink@unifr.ch (A. Petri-Fink).

1 These authors have contributed equally to this work.
}

with engineered nanomaterials are just some of the reasons for the comparatively slow development of nanomedicines.

Nanoparticles (NPs) or sources of NPs can be classified as natural or intentional/engineered and unintentional anthropogenic activities [4]. Humans can come in contact with engineered NPs in many different ways such as through the use of consumer products containing NPs (i.e. food and cosmetic products), at the working place (i.e. occupational exposure), during disposal of the products (i.e. incineration) or by the intended use of NPs in biomedical applications. The possible portals where those NPs may enter the human body are the lungs via inhalation, the gastro-intestinal tract via digestion, the skin, and blood vessels via intravenous injection [5]. No matter if the exposure is intended or occupational, NPs will interact at a certain time with the cells of the human body. One particular fraction of engineered NPs may be defined as 'designer' particles, having a desired functionality. These particles are synthesized mostly within the walls of academic and research centers laboratories generally aiming at obtaining uniform particles. In recent years, a lot of progress was made in the synthesis of such designer NPs, which have been designed in many sizes and morphologies [6-8] to produce distinct optical, magnetic, and physico-chemical properties. 
Over the past two decades, much research has been dedicated to the study of NP-cell interactions in order to advance nanomedical applications, while determining if the potential benefits of nanotechnology could be achieved without any adverse impact upon human health. More specifically, significant effort has been dedicated to elucidate the impact of physicochemical properties of NPs, such as their size, surface charge, hydrophobicity or shape, on their interaction with cells. This interaction is routinely assessed in vitro to reveal mechanistic insights [9-11]. Despite the overwhelming use of in vitro systems to evaluate cellular responses toward NPs, the impact of an omnipresent complex physiological fluid on the material is still insufficiently taken into consideration [12-14].

\section{Physiological fluids}

Upon contact with physiological fluids, NPs can interact with a wide range of biomacromolecules [15], with various consequences. In order to understand the behavior of NPs in physiological fluids it is imperative to summarize the composition of the non-cellular compartments, such as mucus (gastro-intestinal (GI) or respiratory tract) or aqueous lining layer covered by surfactant (lung parenchyma), the blood or the lymphatic fluid, as well as available methods to investigate the possible interactions.

\subsection{Mucus}

Mucus is a biopolymer-based hydrogel produced by specific cells such as goblet cells and its main function is the protection of epithelium against infectious agents. Mucus is rich in water (>95\%) and glycoproteins but also contains enzymes, immunoglobulins, proteins and salts, with the composition varying between each mucosal surface $[16,17]$. If particles are ingested or inhaled, they ; can be deposited onto the mucus, and through subsequent displacement entrapped in mucin fiber mesh, depending on their size.

The interaction of NPs with the mucus can cause a change in particle size and zeta potential. The majority of experiments to study these parameters are usually performed using isolated mucus collected from animals [18]. Recently it has been shown that small-angle neutron scattering (SANS) is a powerful technique to Investigate the interaction of mucus proteins/enzymes with NPs and enables to correlate the changes in comparison to the bare
NPs with mucus permeation [19]. Recently, a combination of tools, such as cryo-scanning electron microscopy, capillary penetration, and optical tweezers, was applied to assess particle mobility in mucus and model hydrogels, and penetration of particles on various length scales. It has been shown that particle mobility is dependent on the highly rigid structures within the mucus mesh but also on the adhesive properties of the particles [20]. In addition to the physicochemical parameters, the muco-adhesive properties of NPs can be determined by applying rheological measurements [21]. Another possibility is to use the Ussing chamber. With it, it has been demonstrated that the diffusion efficiency of neutral NPs was higher in comparison to uncharged particles [22]. In addition, the $\mathrm{pH}$ of mucus varies according to the location within the body, and the interaction of NPs with the mucin polymers can be tuned by buffer conditions such as $\mathrm{pH}$ and ionic strength [23].

The respiratory tract is covered by pulmonary surfactant, which consists $85-90 \%$ of phospholipids and specific surfactant proteins (SP) [24]. The binding of those constituents onto the surface of a $\mathrm{NP}$ can be determined by thin layer chromatography for lipids and gel electrophoresis (SDS-Page) combined with liquid chromatography/tandem mass spectrometry (LC/MS/MS). By using a specific fixation method to stabilize the phospholipids and liquid lining layer, Raemy et al. have shown that it is possible to visualize NPs in the aqueous lining layer (Fig. 1), indicating that this is an important compartment where particle properties can change, depending on the environment [25].

The airway mucus varies in composition and amount along the airway tree. The airway epithelial goblet cells and submucosal glands secrete mucus, forming a two-layer mucus blanket over the ciliated epithelium, i.e. a low-viscosity sol layer covered by a high-viscosity gel layer and a glycocalyx [26]. Insoluble particles are trapped in the gel layer and are moved toward the pharynx (and ultimately to the GI tract) by the upward movement of mucus generated via metachronous beating of the cilia also known as mucociliary clearance. The aqueous lining layer height in the lung parenchyma is very thin, i.e. about $5 \mu \mathrm{m}$ as reported for primary human epithelial type II cells in culture [27], therefore, the volume is also very small and makes it difficult to collect it in vitro or in vivo to determine the colloidal behavior of NP in this liquid. An alternative approach is to use artificial alveolar fluid, and it has been shown that incubation of this liquid with silver NPs induces aggregation

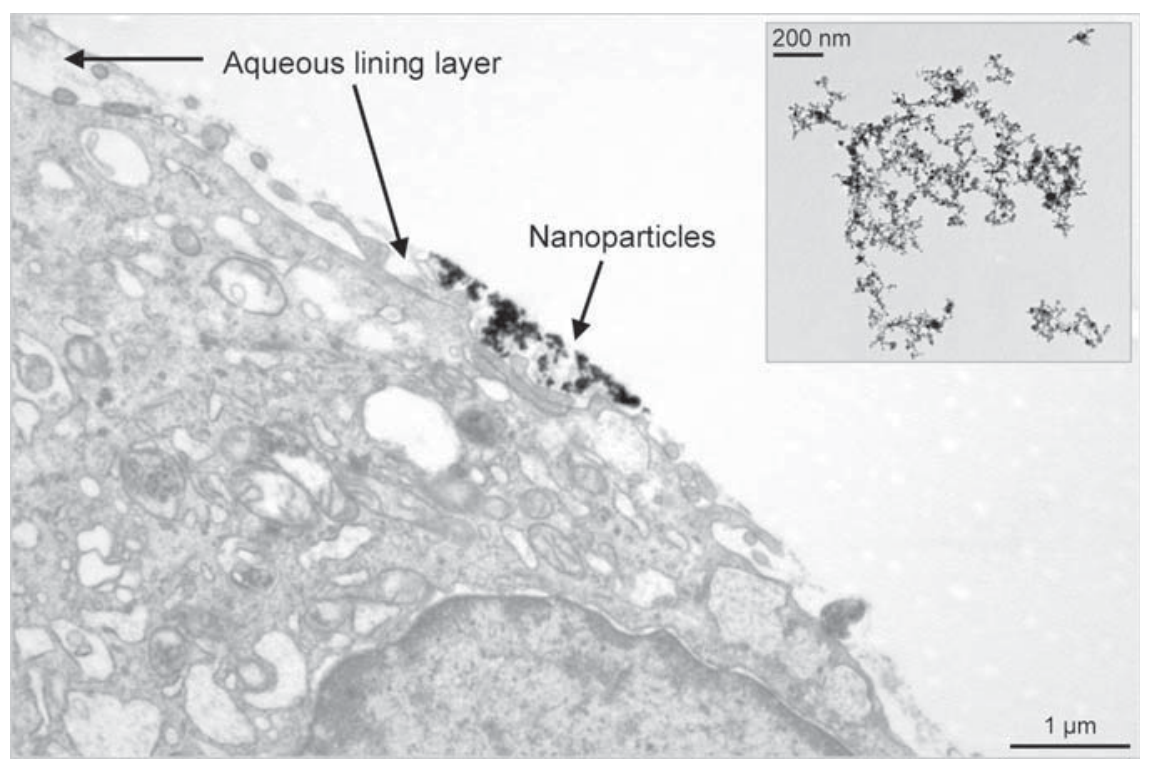

Fig. 1. TEM micrograph of a human epithelial II cell in vitro (A549 cells) incubated at the air-liquid interface and exposed to aerosolized NPs (inset). After 10 min of incubation the NPs are mainly localized in the aqueous lining layer formed by the cells before they are internalized. 
which was confirmed by transmission electron microscopy and dynamic light scattering experiments [28].

\subsection{Blood}

The main administration route up to date for biomedical NPs such as theranostic NPs is via intravenous injection [29], where the NPs encounter a complex cellular and molecular milieu of the human blood [30]. The human blood is composed of a cellular fraction ( $45 \%)$, i.e. red blood cells, white cells and platelets, and the blood plasma ( $\sim 55 \%$ ) with proteins, glucose, amino acids, fatty acids and others such as clotting proteins, i.e. fibrinogens. The term "blood serum" refers to plasma from which fibrinogen has been removed. Blood contains more than 1000 types of proteins and over 50 of them have been identified in various experiments on the surface of NPs [15,31]. Recent findings have also shown that incubating NPs with human plasma, from subjects with different diseases and medical conditions, results in protein coronas of different composition [32]. Since blood composition is highly complex, the analysis of the NP behavior in complete (human) blood is very challenging and the studies are usually done in vitro using defined suspension conditions and/or in vivo experiments (for a review see Hall et al. [33]). Indeed, most research is focused on the identification of surface adsorbed proteins on NPs with respect to their physicochemical properties [34].

One approach to characterize aggregation and the proteins adsorbed onto the surface of magnetic NPs is to separate the NPprotein complex after injection into the blood stream of rats by a high magnetic field gradient magnetic reactor [35]. It was reported that the protein composition depends on the initial surface charge of different functionalized NPs [36]. By using a similar approach, i.e. incubation of magnetic NPs with $10 \%$ fetal bovine serum and a subsequent isolation using a magnetic reactor, the size and surface charge were characterized using dynamic light scattering. Although the adsorbed protein profile was similar on differently charged NPs, the positively charged NPs displayed significantly lower colloidal stability [37].

\subsection{Lymph fluid}

Lymph fluid is formed by interstitial fluid collection through the lymph capillaries and is then transported via the lymph vessels to the lymph nodes. The composition of lymph is similar to blood plasma but contains only white blood cells. Since NPs have been observed in the lymph nodes, a transport from the primary barriers into the lymph capillaries must have occurred [38,39]. This transport might occur via single NPs, small aggregates, or NPs inside immune cells, i.e. dendritic cells. Although it has been shown recently in vivo that the transport of quantum dots from the vaginal lumen to the lymph nodes can be explained by convective diffusion from the interstitial fluid into the lymph capillaries [40], the colloidal characteristics of NPs in this physiological fluid are still unknown and more research in this area is needed.

\subsection{Cell culture media}

Since the mucus and blood fluids are incredibly complex and the vast majority of studies in the field are done in vitro, most research to assess the colloidal behavior of NPs in physiological fluids are done in complete, i.e. serum supplemented cell culture media. Depending on cell type, a specific medium is used to culture cells in vitro. We refer the reader to specialized reviews [41] that describe the composition between the most common cell culture media.

Fig. 2 schematically shows the crowded environment of a NP (represented as $40 \mathrm{~nm}$ Au sphere) in a standard complete cell culture medium (e.g. Dulbecco/Vogt modified Eagle's medium (DMEM) supplemented with $10 \%$ fetal bovine serum (FBS)). The

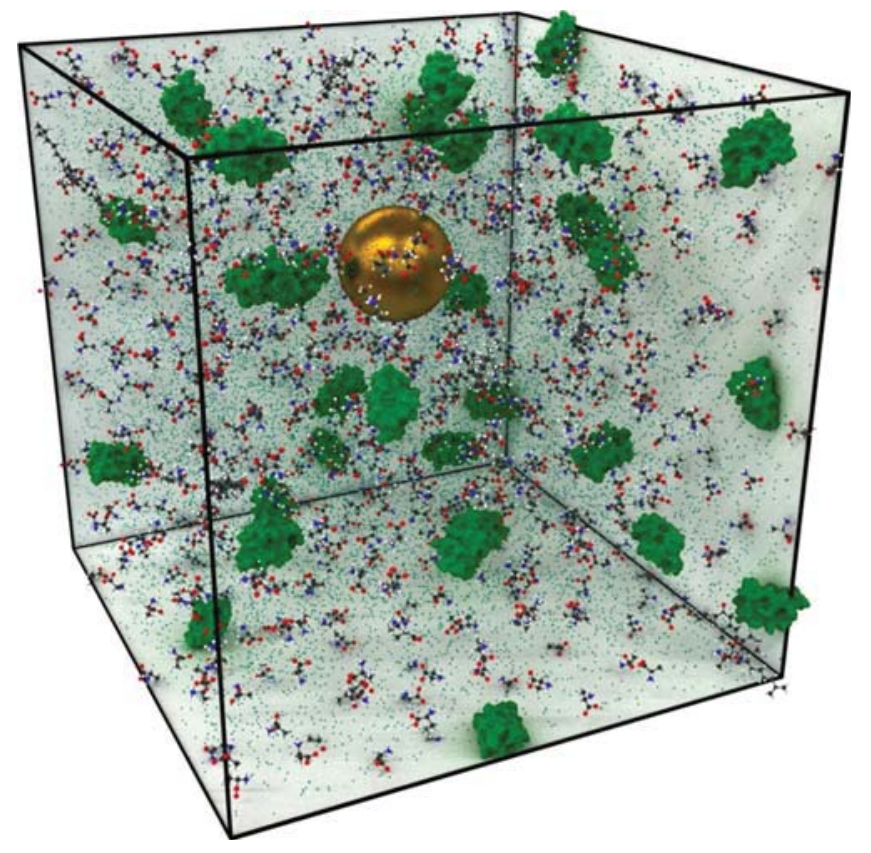

Fig. 2. Scaled illustration of an Au NP incubated into 10\% serum-supplemented cell culture medium. Scale ratio 1:2.5 $\times 10^{18}$ based on the volume occupied of $250 \mu \mathrm{L}$ in a 96-well plate.

medium can be described as a buffered solution containing proteins such as serum albumin, globulins, other biomolecules such as vitamins and amino acids, and ionic salts. The box (cube with $100 \mathrm{~nm}$ side length) represents the volume of medium in which only one NP (at an incubation concentration of $20 \mu \mathrm{g} / \mathrm{mL}$ ) is present. The environment of the NP in this box includes roughly 6400 amino acids, almost 100 vitamin molecules and more than 240,000 ions (cations and anions), represented as green dots, in addition to roughly 34 proteins.

Thus, NP behavior in such an environment will be dictated by the interaction with these components. This interaction can have major consequences, some of which are schematically shown in Fig. 3.

First, it can result in a tightly bound immobile protein layer formed on the particle surface (the so-called hard corona) and possibly a weakly associated mobile layer (the soft corona) [42]. Many studies have focused on identifying the major protein constituents, with the protein corona having shown to be determined by one or more characteristics of the NP, such as material composition, size, hydrophobicity, or charge [37,42]. Much of the information regarding the interaction of proteins and NPs have been summarized in several excellent reviews, which the reader is referred to $[15,43]$.

Second, the interaction of NPs with physiological fluids can induce NP aggregation, which is a common phenomenon in this complex environment and should therefore be taken into account [44]. Aggregation refers to the, usually irreversible, inter-particular adherence, leading to the formation of large and irregularly shaped clusters [45]. This aggregation can lead to misrepresentative results and hamper experimental reproducibility [12]. For example, Wick et al. observed a more pronounced cytotoxic effect for aggregated carbon nanotubes compared to bundled carbon nanotubes, confirming the hypothesis that aggregation phenomena occur and can modify the cytotoxicity of a nanomaterial [46]. Cho and colleagues [9] showed, by using an upright and an inverted cell culture configuration, that the cellular uptake of gold NPs was generally higher in the upright configuration and that cellular uptake between the two configurations was most prominent for gold NPs with higher sedimentation rates. This additionally highlights the necessity of 
A

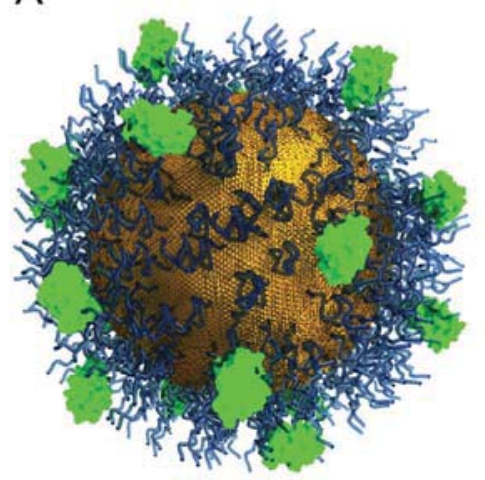

C

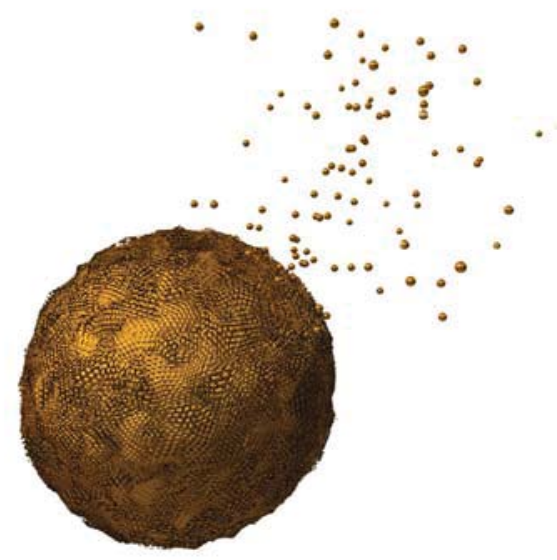

B

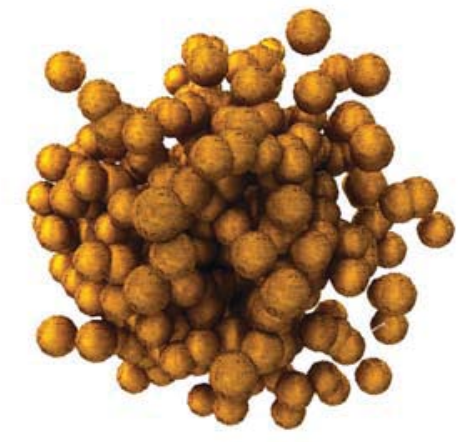

D

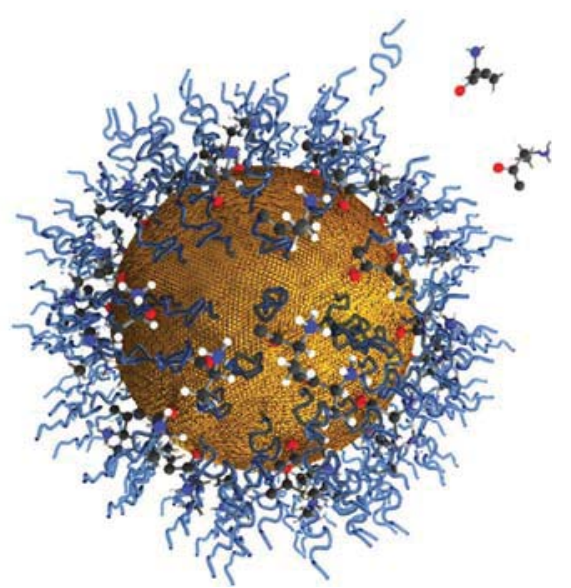

Fig. 3. Schematic illustration of possible consequences arising from NP incubation in physiological fluids. (A) Formation of protein corona; (B) NP aggregation; (C) NP dissolution; (D) removal/exchange of anchoring ligands.

taking into account sedimentation and diffusion, which can vary wildly for aggregates. In a recent review, we have described the current state-of-the art, the theory behind it, current bottlenecks in this field [41].

Third, some NPs, in particular silver $(\mathrm{Ag})$ and copper $(\mathrm{Cu})$, have been reported to undergo oxidative dissolution. Ion release was found to correlate with intrinsic NP properties, such as particle size, shape and surface coating, but also with matrix factors, such as dissolved oxygen, temperature, $\mathrm{pH}$, ionic strength and the presence of proteins [47-49]. For example, Ostermeyer et al. have shown that increased concentrations of bovine serum albumin (BSA) result in increased dissolution rates of Ag NPs due to the high affinity of BSA toward $\mathrm{Ag}^{+}$ions chemisorbed on the Ag NP surface [48].

Finally, the presence of biomolecules was reported to be responsible for the removal of anchoring ligands from NP surfaces. Several studies have shown that physiological concentrations of thiolcontaining molecules such as cysteine easily displace, for example, thiolated Polyethylene-glycol (PEG) from the surface of Au NPs [50,51]. The (partial) loss of the ligand, however, has far-reaching consequences as it impacts colloidal stability of the core NP, changes the adsorbed protein profile, and may lead to the complete loss of any functional grafted ligands such as fluorescent dyes, antibodies, or drug molecules.

\section{Characterization of NPs in physiological fluids}

The characterization of NPs in physiological fluids and the assessment of their colloidal behavior are challenging due to the complex physical and chemical forces involved, the multitude of different, highly complex physiological fluids, and the variety and complexity of analytical methods and theories upon which these methods are based. However, there are some techniques that are regularly used to study the behavior of NPs in complex fluids, as well as a growing number of novel methods that have emerged in recent years. Here we discuss the most commonly used experimental techniques and comment on considerations that must be made when characterizing such complex systems. It is important to mention that most of the research in this area is performed with NPs in serum completed cell culture media since the composition of this fluid can be controlled.

In this review, we focus on metallic NPs, most frequently silver $\mathrm{Ag})$ and gold $\mathrm{(Au})$, which exhibit outstanding physical and chemical properties that are markedly different from the bulk metal [52]. The most important property of these NPs is the so-called localized surface plasmon resonance (LSPR) which is generated by the collective oscillation of conduction band electrons upon excitation with the appropriate electromagnetic radiation (e.g. a laser beam), resulting in a characteristic light scattering and absorption spectrum, which is a function of the particle size, morphology, and the local dielectric environment $[53,54]$. This consequently makes plasmonic NPs excellent probes for many analytical techniques that rely on light scattering and absorption. Due to their outstanding optical properties, an increasing number of studies have focused on Au for a wide range of biological and biomedical applications such as biosensing, biomedical imaging, gene and drug delivery, or disease detection $[55,56]$.

Tables 1 and 2 summarize typical NPs, organized by the main analytical method used to characterize them in a variety of 
Table 1

Dynamic light scattering of typical plasmonic NPs in a variety of physiological fluids.

\begin{tabular}{|c|c|c|c|}
\hline Reference & NP type & Fluid(s) & Content \\
\hline Albanese (2011) [57] & Au NPs and TF coated Au aggregates & RPMI & $\begin{array}{l}\text { Effect of aggregation on cellular uptake } \\
\text { and cytotoxicity }\end{array}$ \\
\hline Balog (2015) [58] & $\begin{array}{l}\text { Au NPs (citrate, } \mathrm{COOH}-\mathrm{PEG}, \mathrm{NH}_{2} \text {-PEG } \\
\text { and methoxy-PEG coated) }\end{array}$ & DMEM, DMEM containing 10\%FBS & $\begin{array}{l}\text { Characterizing state of aggregation in } \\
\text { physiological fluid }\end{array}$ \\
\hline Braydich-Stolle (2014) [28] & Ag NPs (Bare and polysaccharide coated) & Alveolar and lysosomal fluid & Stability and aggregation \\
\hline Casals (2010) [59] & Au NPs & Complete cell media & Evolution of protein corona \\
\hline Casals (2011) [60] & Au and Ag NPs & Complete cell media & $\begin{array}{l}\text { Protein corona formation and biological } \\
\text { implications }\end{array}$ \\
\hline Cho (2011) [9] & Au NPs (bare and PEG coated) & Complete cell media & $\begin{array}{l}\text { Influence of sedimentation and diffusion } \\
\text { on cellular uptake }\end{array}$ \\
\hline De Paoli Lacerda (2010) [61] & Au NPs & Protein solutions & $\begin{array}{l}\text { Interaction of NPs with human blood } \\
\text { proteins }\end{array}$ \\
\hline Dominguez-Medina (2013) [62] & Au NPs (citrate coated) & PBS and BSA solutions & $\begin{array}{l}\text { Synthesis of advanced NPs to prevent } \\
\text { aggregation }\end{array}$ \\
\hline Fatisson (2012) [63] & Au NPs & Complete cell media & $\begin{array}{l}\text { Impact of cell culture media components } \\
\text { on stability }\end{array}$ \\
\hline Hühn (2013) [64] & $\begin{array}{l}\text { Au NPs (negatively and positively } \\
\text { charged polymers) }\end{array}$ & $\begin{array}{l}\text { Complete cell media with increasing } \\
\text { complexity }\end{array}$ & $\begin{array}{l}\text { Charge-dependent interactions with } \\
\text { proteins and cells }\end{array}$ \\
\hline Kittler (2010) [65] & Ag NPs (PVP or citrate coated) & Complete cell media & $\begin{array}{l}\text { Effect of proteins on dispersability and } \\
\text { biological activity of NPs }\end{array}$ \\
\hline Lankoff (2012) [66] & Ag NPs & Complete cell media (5\% FBS) & Impact of aggregation on cellular response \\
\hline $\operatorname{Li}(2015)[67]$ & Cu NPs & Complete cell media & Dissolution of NPs in cell culture media \\
\hline Liu $(2012)[68]$ & Au nanorods (CTAB coated) & BSA, HSA, IgG & Interaction with proteins \\
\hline McCuspie (2011) [69] & Ag NPs (BSA coated) & Synthetic lung fluid & $\begin{array}{l}\text { Dispersion stabilization of NPs and effect } \\
\text { on colloidal stability }\end{array}$ \\
\hline Mahl (2010) [70] & Au NPs (TPPTS and PVP coated) & Complete cell media (FBS up to $10 \%$ ) & $\begin{array}{l}\text { Stability and aggregation; Impact on } \\
\text { cellular response }\end{array}$ \\
\hline Montes-Burgos (2010) [71] & Au NPs & Human blood plasma & Protein adsorption and stability \\
\hline Moyano (2014) [72] & Au NPs (sulfobetain headgroups) & Diluted human serum & Synthesis of corona-free NPs \\
\hline Mukherjee (2014) [73] & Ag NPs & Complete cell media & $\begin{array}{l}\text { Impact of physiological interactions on } \\
\text { cellular dosimetry }\end{array}$ \\
\hline Murdock (2008) [13] & $\mathrm{Cu}$ and $\mathrm{Ag}$ NPs & Complete cell media & $\begin{array}{l}\text { Characterization of NP dispersion in cell } \\
\text { media }\end{array}$ \\
\hline Pal (2014) [74] & Ni NPs & Complete cell media & $\begin{array}{l}\text { Characterization of NP dispersion in } \\
\text { complex media and dosimetry }\end{array}$ \\
\hline Pyshnaya (2014) [75] & $\begin{array}{l}\text { Au nanorods and spheres (PEI and BSA } \\
\text { coated) }\end{array}$ & Complete cell & $\begin{array}{l}\text { Impact of physiological fluids on size and } \\
\text { stability }\end{array}$ \\
\hline Soliman (2015) [76] & Au nanorods & Complete cell media & $\begin{array}{l}\text { Method development to improve stability } \\
\text { in media }\end{array}$ \\
\hline
\end{tabular}

BSA, bovine serum albumin; PVP, polyvinyl pyrrolidone; PEI, polyethyleneimine; FBS, fetal bovine serum; DMEM, Dulbecco's modified Eagle's medium; RPMI, Roswell Par Memorial Institute medium; LSPR, localized surface plasmon resonance; HSA, human serum albumin; TF, transferrin; TPPTS, tris(sodium-m-sulfonatophenyl)phosphine.

physiological fluids. Approaches described in more detail include: dynamic light scattering (DLS) (Table 1), optical spectroscopies, in particular UV-is and microscopy, with a special focus on dark field hyperspectral imaging (DF-HSI) (Table 2), in addition to an overview of less commonly used techniques. It should be noted, however, that there is rarely one technique that can fully characterize a NP in a physiological fluid and often the most reliable conclusions will be drawn from an array of complementary measurements.

\subsection{Scattering}

Due to easy sample preparation and a simple experimental procedure as well as the availability of high-quality instruments, DLS is usually one of the first techniques to probe (plasmonic) NPs. It is also the most abundantly used in particular in the context of physiological fluids (Table 1 ).

Theoretical results are available for many particle morphologies as well as for aggregates and agglomerates of spherical particles, which are however most frequently attributed with the features of statistically self-similar random mass fractals. Light scattering builds on the experience that an interaction between the NPs and biomolecules will be accompanied by changes in the hydrodynamic size of the particles. The constituent of the fluids may have an impact on stability [63], and therefore, the most frequent use is to answer whether the system remains stable or undergoes aggregation $[13,28,59,60,65,69,75]$. It has been repeatedly shown that the degree of aggregation has an impact on cellular response $[70,77]$ and much effort is dedicated to improve the stability of NPs in such media [76]. Although it has been demonstrated that protein adsorption can generally stabilize the system [62,68,71], surface-charge dependent interactions must be also considered [64]; characterizing the extent and time evolution of protein adsorption may bring further insights $[60,72]$. Other studies have used the method to study kinetics of aggregation and dissolution of e.g. $\mathrm{Ag}$ and $\mathrm{Cu}$ particles [67]. Two very important factors to be considered are particle polydispersity [78] and the variety of the physiological fluids. Since DLS is an ensemble technique where billions of scattering centers are probed simultaneously, proteins, which are highly abundant in complex fluids, contribute to scattering and if this contribution is not negligible compared to the NPs, e.g. at low concentrations, the analysis and interpretation must allow distinction between scattering from NPs and those proteins. This may be achieved by characterizing the physiological fluid alone without NPs, the NPs in an 'empty background' e.g. in water, and then finally the NPs in the fluid. Nonetheless, this approach is valid only if the interaction between NPs and the proteins is moderate, in the sense that the overall number of 'free' proteins does not change considerably. However, as soon as NP-protein complexation occurs, this approach should not be followed, as the 'reference scattering' from the protein alone is not valid anymore. In this regard depolarized scattering provides a promising alternative to characterize NP in physiological fluids, which relies on the optical anisotropy of even spherical plasmonic NPs [79], which either stems from shape and/or from internal 
Table 2

Studies on plasmonic NPs in physiological fluids using spectroscopic or microscopy methods.

\begin{tabular}{|c|c|c|c|}
\hline Reference & NP type & Fluid(s) & Content \\
\hline \multicolumn{4}{|c|}{ Dark field microscopy \& hyperspectral imaging (DF-HSI) } \\
\hline Badireddy (2012) [83] & $\begin{array}{l}\mathrm{Ag}, \text { Au but also CNT, } \mathrm{CeO}, \mathrm{TiO}_{2} \mathrm{NPs} \\
\text { (citrate and PVP coated) }\end{array}$ & Water and simulated waste water & $\begin{array}{l}\text { Detection and characterization of NPs in } \\
\text { complex (waste) water }\end{array}$ \\
\hline Hu (2008) [84] & Au nanorods and shells & Water & $\begin{array}{l}\text { Understanding factors that influence LSPR } \\
\text { of NPs }\end{array}$ \\
\hline Huang (2006) [85] & $\begin{array}{l}\text { Au nanorods and spheres (antibody } \\
\text { coated) }\end{array}$ & Complete cell media and intracellular & Au nanorods for photothermal therapy \\
\hline Jenkins (2015) [81] & Au NPs (citrate coated) & Blood & Monitoring LSPR for aggregation studies \\
\hline Leclerc (2014) [86] & Ag NPs (bare and cysteine coated) & Complete cell media and intracellular & Dissolution and reformation of silver NPs \\
\hline Mortimer (2014) [87] & $\mathrm{Ag}, \mathrm{Au}, \mathrm{CuO}, \mathrm{TiO}_{2}$, NPs and QDs & $\begin{array}{l}\text { Intracellular and } 10 \mathrm{mM} \text { HEPES } \\
\text { buffer }\end{array}$ & $\begin{array}{l}\text { Semi-quantitative analysis of cellular } \\
\text { uptake }\end{array}$ \\
\hline Rosman (2012) [88] & $\begin{array}{l}\text { Au nanorods and spheres }\left(\mathrm{NH}_{2}-\text { or }\right. \\
\text { COOH-PEG coated })\end{array}$ & Intracellular & $\begin{array}{l}\text { Assessment of NP uptake and aggregation } \\
\text { inside cells }\end{array}$ \\
\hline Stacy (2013) [89] & Au nanorods (tannic acid coated) & Water and cell culture media & Detection of nanorods in cells \\
\hline \multicolumn{4}{|c|}{ Transmission electron microscopy (TEM) } \\
\hline Hirsch (2014) [77] & Au NPs & Water & $\begin{array}{l}\text { Cryo-TEM; Effect of surface charge on } \\
\text { colloidal stability and cell interaction }\end{array}$ \\
\hline Hondow (2012) [90] & Au NPs and QDs & $\begin{array}{l}\text { McCoy's 5A (modified) Media } \\
\text { containing } 10 \% \text { FBS }\end{array}$ & $\begin{array}{l}\text { Cryo-TEM; Quantitative characterization of } \\
\text { NP aggregation }\end{array}$ \\
\hline Rosman (2012) [88] & $\begin{array}{l}\text { Au nanorods and spheres }\left(\mathrm{NH}_{2}-\text { or }\right. \\
\text { COOH-PEG coated })\end{array}$ & Intracellular & $\begin{array}{l}\text { Assessment of NP uptake and aggregation } \\
\text { inside cells }\end{array}$ \\
\hline Zhang (2014) [91] & Au spheres (Citrate coated) & Water & Interaction between biomolecules and $\mathrm{Au}$ \\
\hline \multicolumn{4}{|l|}{ Fluorescence spectroscopy } \\
\hline De Paoli Lacerda (2010) [61] & Au NPs & Protein solutions & $\begin{array}{l}\text { Interaction of NPs with human blood } \\
\text { proteins }\end{array}$ \\
\hline Huang (2014) [92] & $\begin{array}{l}\text { Au NPs (thiol group containing } \\
\text { coatings) }\end{array}$ & PBS and BSA solutions & $\begin{array}{l}\text { Conformational changes of adsorbed } \\
\text { proteins on NPs }\end{array}$ \\
\hline Maffre (2011) [93] & $\begin{array}{l}\text { FePt NPs (amphiphilic polymer } \\
\text { coated, fluorescently labeled }\end{array}$ & Protein solutions & $\begin{array}{l}\text { Characterization of protein adsorption on } \\
\text { NPs }\end{array}$ \\
\hline \multicolumn{4}{|r|}{ No1 5} \\
\hline Albanese (2011) [57] & Au NPs (TF coated Au aggregates) & RPMI & $\begin{array}{l}\text { Effect of aggregation on cell uptake and } \\
\text { toxicity }\end{array}$ \\
\hline Balog (2015) [58] & $\begin{array}{l}\text { Au NPs (citrate, } \mathrm{COOH}-\mathrm{PEG}, \mathrm{NH}_{2} \text {-PEG } \\
\text { and methoxy-PEG coated) }\end{array}$ & DMEM, complete DMEM & Characterizing NPs in physiological fluids \\
\hline Chanana (2013) [94] & Au NPs (protein coated) & PBS protease solution & $\begin{array}{l}\text { Properties of protein-coated NPs before } \\
\text { and after proteolytic digestion }\end{array}$ \\
\hline De Paoli Lacerda (20100 [61] & Au NPs & Protein solutions & $\begin{array}{l}\text { Interaction of NPs with human blood } \\
\text { proteins }\end{array}$ \\
\hline Dominguez-Medina (2013) [62] & Au NPs (citrate coated) & PBS and BSA solutions & $\begin{array}{l}\text { Synthesis of advanced NPs to prevent } \\
\text { aggregation }\end{array}$ \\
\hline Garcia (2015) [95] & $\begin{array}{l}\text { Au nanorods and spheres (glycan and } \\
\text { PEG-coated) }\end{array}$ & $10 \%$ FBS in PBS and DMEM & $\begin{array}{l}\text { Stability and targeting in protein rich } \\
\text { media }\end{array}$ \\
\hline Pyshnaya (2014) [75] & $\begin{array}{l}\text { Au nanorods and spheres (PEI and } \\
\text { BSA coated) }\end{array}$ & DMEM containing $10 \%$ FBS & $\begin{array}{l}\text { Impact of physiological fluids on size and } \\
\text { stability }\end{array}$ \\
\hline McCuspie (2011) [96] & Ag NPs (BSA coated) & Synthetic lung fluid & $\begin{array}{l}\text { Dispersion stabilization of NPs and effect } \\
\text { on colloidal stability }\end{array}$ \\
\hline Jenkins (2015) [81] & Au NPs (citrate coated) & Blood & Monitoring LSPR for aggregation studies \\
\hline $\operatorname{Kah}(2014)[97]$ & $\begin{array}{l}\text { Au nanorods (amphi-philic ligands } \\
\text { coating) }\end{array}$ & RPMI & Effect of NP coating on cellular response \\
\hline Mahmoudi (2011) [98] & Magnetic NPs (Au coated) & FBS solution & $\begin{array}{l}\text { Enhancement of uptake via carbon } \\
\text { nanotubes }\end{array}$ \\
\hline Oster-meyer (2013) [48] & $\begin{array}{l}\text { BSA coated Ag NPs and } \\
\text { Alginate-coated Au NPs }\end{array}$ & HEPES buffer and wastewater & Dissolution through LSPR changes \\
\hline Soliman (2015) [76] & $\begin{array}{l}\text { Ag prisms, Au spheres and nanorods } \\
\text { (amphi-philic polymer coated) }\end{array}$ & $\begin{array}{l}\text { DMEM and DMEM containing } 10 \% \\
\text { FBS }\end{array}$ & $\begin{array}{l}\text { Method development to improve stability } \\
\text { in media }\end{array}$ \\
\hline Tebbe (2015) [99] & Au nanorods (protein coated) & $\begin{array}{l}\text { DMEM and DMEM containing 10\% } \\
\text { FBS }\end{array}$ & Stability of protein-coated NPs in media \\
\hline Zhang (2014) [91] & Au spheres (citrate coated) & Water & $\begin{array}{l}\text { Interaction modes of biomolecules with } \\
\text { NPs }\end{array}$ \\
\hline Zook (2011) [82] & Ag NPs (PEG coated) & DMEM containing BSA & $\begin{array}{l}\text { Studying the dissolution rate of Ag NP in } \\
\text { media }\end{array}$ \\
\hline \multicolumn{4}{|c|}{ Surface-enhanced Raman spectroscopy } \\
\hline $\mathrm{Fu}(2015)[100]$ & AuNPs (HSA coated) & Water & $\begin{array}{l}\text { Overtime structural changes of serum } \\
\text { albumin and NPs interactions }\end{array}$ \\
\hline Jenkins (2015) [81] & Au NPs (citrate coated) & Blood & Monitoring LSPR for aggregation studies \\
\hline
\end{tabular}

BSA, bovine serum albumin; PVP, polyvinyl pyrrolidone; CNTs, carbon nanotubes; QDs: quantum dots; CTAB, cetyl trimethylammonium bromide; PEG, polyethylene glycol; PEI, polyethyleneimine; FBS, fetal bovine serum; DMEM, Dulbecco's modified Eagle's medium; RPMI, Roswell Park Memorial Institute medium; LSPR, localized surface plasmon resonance; MS: mass spectrometry; OES: optical emission spectrometry; HSA, human serum albumin; TRIS: tris(hydroxymethyl)aminomethane; TF: transferrin.

anisotropy. It has been shown that, compared to plasmonic NPs, scattering of depolarized light from the physiological fluid is weak, and thus, excellent 'contrast' with an essentially zero background can be obtained [58].

\subsection{Spectroscopic and microscopy methods (Table 2)}

Compared to the previously described scattering methods, optical spectroscopy is a rapid and facile technique to monitor the 

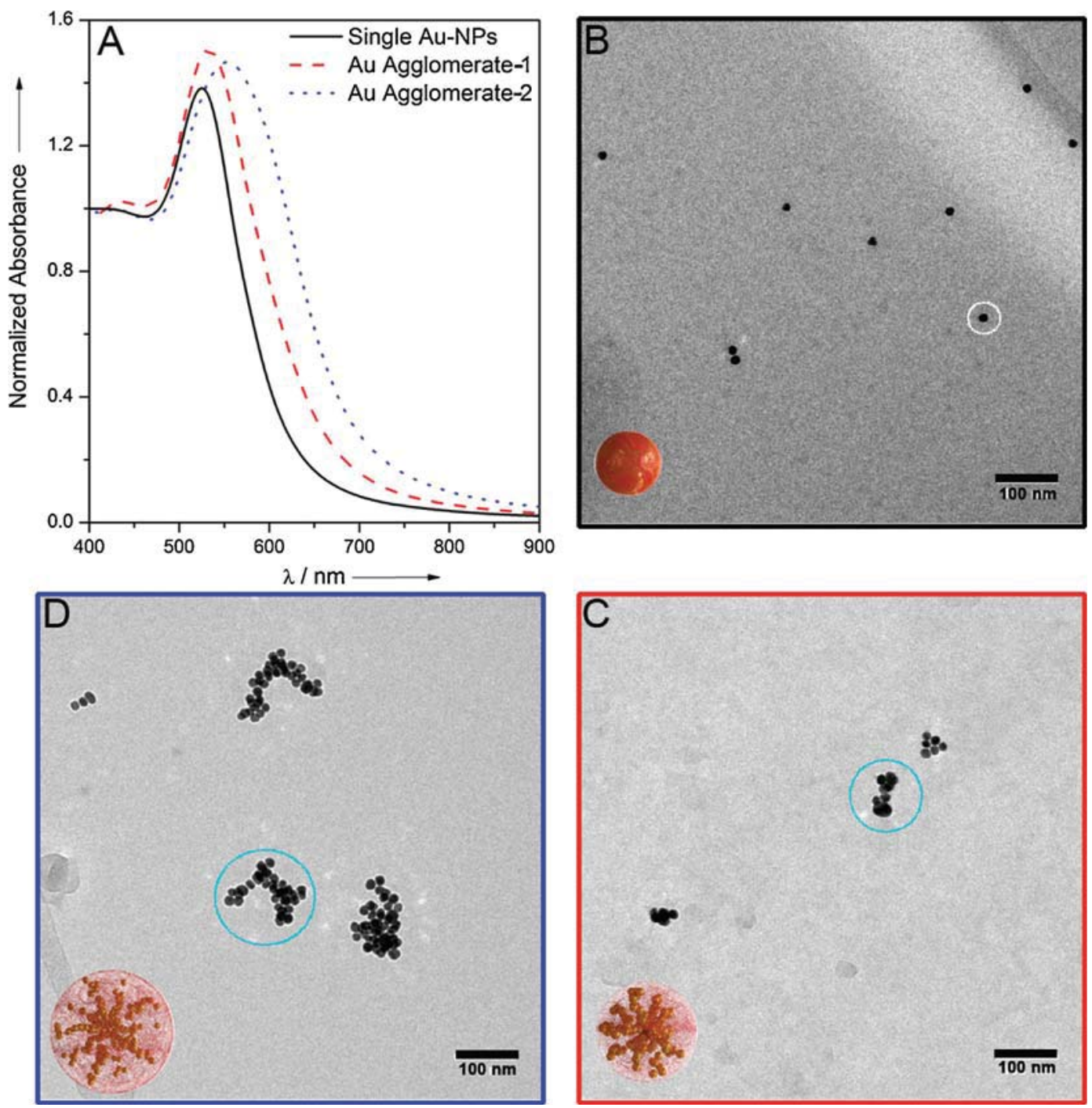

Fig. 4. (A) Extinction spectra of the single Au NPs and two different sizes of Au agglomerates. Cryo-TEM images of (B) single Au NPs and the two types of Au agglomerates (C, D). Reproduced by permission of The Royal Society of Chemistry (http://pubs.rsc.org/en/Content/ArticleLanding/2014/NR/c4nr00460d\#!divAbstract) [77].

colloidal behavior of plasmonic NPs. As explained before, these particles present LSPRs, which are strongly sensitive toward aggregation: individual LSPRs can couple with each other via near-field interactions $[53,54]$, resulting in changes to the position, width, and intensity of the LSPR band. As a consequence, particle aggregation typically results in a red-shift and a broadening of the LSPR absorption peak $[77,80]$.

These changes indicate a decrease in the concentration of single NPs, confirmed by a color shift of the colloid, e.g. from deep red to purple for Au nanospheres and from yellow to black for $\mathrm{Ag}$ nanospheres. Therefore, many studies have reported the colloidal behavior of plasmonic NPs in biological media with UV-Vis Balog et al. [58] demonstrated that citrate coated Au NPs aggregated in $10 \%$ FBS supplemented cell culture media, while PEG-coated Au NPs were completely stable. Plasmonic NPs functionalized with various surface ligands, such as Au and Ag NPs with dodecyl grafted poly(isobutylene-alt-maleic-anhydride) or glycan-coated Au nanorods [95], have been recently prepared by various groups in order to improve colloidal stability in protein-rich environments. Albanese and Chan [57] developed a simple technique to produce transferrin coated Au NP aggregates of different sizes and characterized their colloidal stability through the changes of the LSPR band. Although UV-Vis can readily distinguish primary NPs from agglomerated plasmonic NPs, the signal can be compromised by the extremely high optical density and opacity of some physiological fluids, e.g. blood [81] (Fig. 4).

UV-Vis spectroscopy has also been used to study, and even quantify, the dissolution of plasmonic NPs. Zook et al. [82] and Ostermeyer et al. [48] quantified Ag NP dissolution by measuring the LSPR intensity over time and comparing the sample's intensity against the LSPR intensity of a Ag NP standard curve. Unlike most existing methods, the estimation of Ag dissolution by UV-Vis allows the measurement of the concentration of $\mathrm{Ag}^{0}$ within the NPs even in complex fluids containing chloride anions at very high concentration, since dissolved $\mathrm{Ag}^{+}$or $\mathrm{AgCl}$ particles do not have an associated LSPR band. In addition, no separation step is required to separate the particles from the dissolved species. However, this method only applies for single Ag NPs since the aggregation process will also affect the LSPR intensity.

In certain cases, UV-Vis is suitable for monitoring particleprotein interactions as the LSPR is sensitive to the local dielectric environment [54]. For this, plasmonic NPs are incubated in media of interest and, due to the formation of a protein corona, their LSPR exhibits a slight red shift and an increase in intensity over time. Many papers have used the technique for this purpose, as shown in Table 2. Protein adsorption on Au and Ag NPs has been investigated 

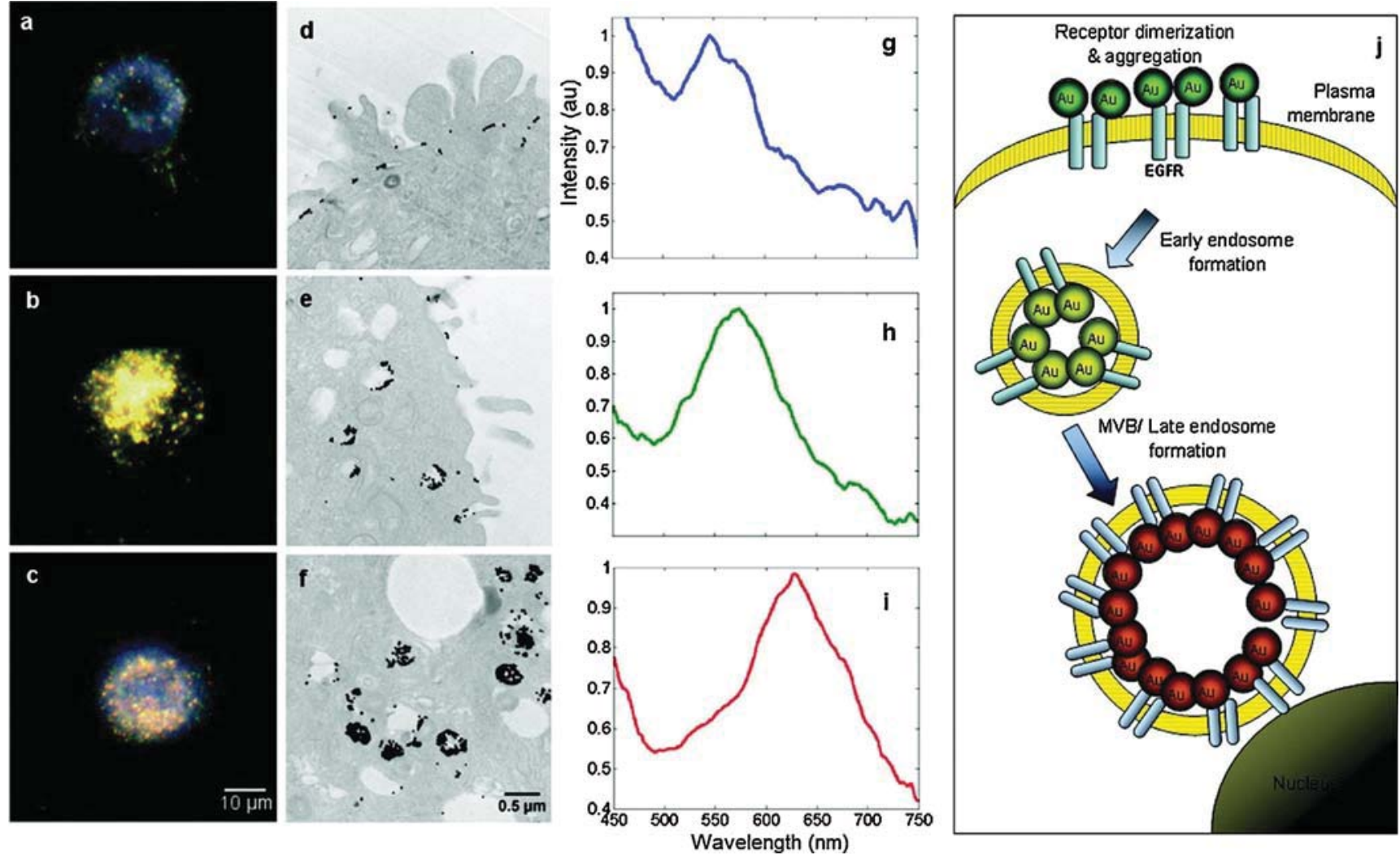

Fig. 5. Dark field micrographs of A431 cells incubated with $25 \mathrm{~nm}$ anti-epidermal growth factor receptor Au NP conjugates at $4{ }^{\circ} \mathrm{C}$ (a) $25^{\circ} \mathrm{C}$ (b) and $37{ }^{\circ} \mathrm{C}(\mathrm{c})$ with the corresponding TEM of identical samples (d, $4^{\circ} \mathrm{C}$; e, $25^{\circ} \mathrm{C}$; and f, $37^{\circ} \mathrm{C}$ ) and mean scattering spectra per cell $\left(\mathrm{g}, 4^{\circ} \mathrm{C}\right.$; h, $25^{\circ} \mathrm{C}$; and i, $37^{\circ} \mathrm{C}$ ). (j) Schematic of the correlation between epidermal growth factor receptor regulation state and color of scattered light. Reprinted with permission from Nano Letters 2009, 9 (10), pp. 3612-3618. Copyright 2009 American Chemical Society [105].

for different types of proteins, such as BSA [96], HSA, globulins, fibrinogen, histones, insulin [61] as well as for serum [98]. While the approach works well for bare or small molecule coated NPs such as citrate coated Au and Ag NPs, care should be taken when particles are coated by polymers, a very common situation. The polymer shell may act as a dielectric spacer and thus decrease the signal upon protein binding, i.e. the increase in refractive index due to protein binding should be close to the plasmonic NP surface in order to have a detectable shift in the LSPR [101]. Balog and colleagues [58] showed that BSA adsorption can be detected for citrate coated Au NPs by UV-Vis as a red-shift of the LSPR, from 519 to $524 \mathrm{~nm}$. However, coating of the Au NPs with PEG did not result in any change of the LSPR band. Therefore, UV-Vis can become practically insensitive under certain conditions and monitoring the protein adsorption of such surface functionalized NPs in biological media only by UV-Vis is not necessarily conclusive and complementary techniques should be used. An alternative technique to study protein adsorption is fluorescence spectroscopy, exploiting the plasmonic NPs' ability to quench the fluorescence of molecules near the particle surface. The quenching efficiency for metallic NPs depends on the distance between the quencher and the chromophore, therefore measurements of quenching by proteins can reveal information about the NP-protein interaction. Moreover, the change in the fluorescence emission maxima arises from a change of protein conformation, which provides additional information on the protein-particle interaction. In addition, protein adsorption can be studied by fluorescence correlation spectroscopy through a decrease in the diffusion coefficient of the chromophore corresponding to an increase in particle size upon protein binding [93]. However, the technique is restricted to fluorescent compounds or fluorophore-functionalized NPs, which often bear other challenges [102].
In contrast to the ensemble characterization methods of UV-Vis and fluorescence spectroscopy, it is now possible to obtain spectral scattering information on a single NP level with high spatial resolution through the use of dark field microscopy (DFM) [103]. In a nutshell, DFM is when white light is focused obliquely onto the sample, using a specialized condenser, and only scattered light is collected by the objective. This light can then be analyzed to give a hyperspectral image, i.e. every pixel of the recorded image has an associated extinction spectra. Given the incredible scattering cross-section of plasmonic NPs (e.g. a $50 \mathrm{~nm}$ gold sphere has a scattering cross-section up to $10^{6}$ fold larger than a fluorescent dye or quantum dot [104], their unique spectrum, and their sensitivity to changes in the local dielectric environment, it is possible to detect and characterize plasmonic NPs in a variety of complex biological fluids and tissues. An example of this is shown in Fig. 5 where DF hyperspectral imaging was used to follow the journey of Au NPs upon endocytosis: small clusters of NPs that scatter green light are present in early endosomes, before they are trafficked to late endosomes that scatter red light due to the formation of larger clusters [105].

One of the earliest applications of DFM was demonstrated by Schultz et al. who could detect and spectrally characterize different sized Ag NPs, as well as locate their specific binding location on a Drosophila chromosome [106]. In a similarly pioneering study, Huang et al. used DFM to show the preferential binding of Au nanospheres and nanorods to cancer cells over healthy cells after functionalization of the NPs with a targeting moiety [85]. Both these studies, among others [107], have applied DFM mostly as a qualitative technique to confirm the presence, and approximate abundance, of the NP of interest. However, as is often the case with microscopy, extracting quantitative characterization data about the state of NPs in biological fluids can be challenging. 
The complexity of interpreting hyperspectral images of plasmonic NPs is most evident by considering the simplified case of a single NP, where the group of Gregory Hartland, among others, has explained the factors contributing to the observed linewidth of a single NP's LSPR [84]. While the NP shape and surface area influence their scattering spectra, the presence of surface bound proteins and other nearby plasmonic NPs, as for the case of agglomerates, can have a drastic, and often challenging to predict, influence on the spectra-as described in the previous section for the case of UV-Vis spectroscopy. Badireddy et al. chose to consider only single Ag NPs with spectra that matched reference spectra, of Ag NPs in water, in order to count their relative abundance in simulatedwetland ecosystem water and wastewater depending on their surface functionality, despite the presence of aggregates [83]. Conversely, Mortimer et al. used reference spectra of NPs dispersed in a cell culture buffer containing extracellular substances, thereby taking into account any fluid-dependent aggregation, resulting in higher numbers of NPs inside the protozoa found compared with when a reference spectra of NPs in water alone was used [87]. Furthermore, they indicated the applicability of semi-quantitative DFM to $\mathrm{Au}, \mathrm{Ag}, \mathrm{Cu}$ oxide, and QDs; however, as in other cases an orthogonal quantification technique, such as ICP-MS or TEM, would have helped validate their approach. A noteworthy example of how DFM can be combined with other techniques was demonstrated by Rosman et al. who used DFM as a low resolution semi-quantitative method to count the number of aggregates present, which was then combined with TEM to identify the number of particles per aggregate [88].

Contrasting with DFM, TEM is likely the most widely applied tool for NP characterization. However, in the case of physiological fluids it is not usually possible due to the high concentration of salts and proteins present which scatter and absorb the electron beam. In addition, drying artifacts [108] are a well-known phenomenon when preparing TEM grids with NPs. One of the few reliable ways to image NPs in, diluted or simulated, physiological fluids is through cryo-TEM, as shown by Hondow et al. who, after plunge freezing could measure the size and packing fraction of quantum dot agglomerates even in the presence of FBS [90]. One of the major drawbacks, however, of cryo-TEM is the expertise and time required to obtain well-prepared samples and perform reliable imaging.

\subsection{Other analytical techniques}

As shown in previous sections, each analytical method has its own advantages and disadvantages, which is why researchers typically resort to a multifaceted approach. Not only new methods are being developed to help characterize NPs but also methods used in different fields of science have begun to find their way into the field and help assess the question of accurate NP characterization.

Thanks to advancements in recent years in the instrumental setup and data acquisition techniques analytical ultracentrifugation (AUC) has become an interesting alternative to measure the size and shape distributions of NPs, and an increasing number of groups have applied this method [82,86]. The theory behind the AUC is using a centrifuge at high rotational speeds, which causes sedimentation in a colloidal suspension. By tracking the different sedimentation velocities of the NPs, estimations can be made about the size and shape distribution of a given sample [109-111]. Zook et al. [82] used this method to measure the size distribution of $\mathrm{Au}$ $\mathrm{NP}$ agglomerates in situ. They were able to distinguish between monomers, dimers, and trimmers, which is non-trivial with DLS. Although AUC proves to be able to bypass problems of in situ measurements, certain assumptions about e.g. coating densities, NPs' and agglomerate's morphology, or absorbance behavior, are required for analysis [82].
Gel electrophoresis is an established method for protein separation and analysis in biochemistry, but can also be used to analyze the interaction between NPs and proteins. Gel electrophoresis is based on the fact that charged molecules or particles move at different velocities, according to their charge to size ratio, when in an electric field. This enables the separation and quantification of different species. Moyano et al. [72] used gel electrophoresis to determine the interaction between NPs and proteins in diluted human serum. They observed that the NP mobility was affected due to protein corona formation. The limitation of the methodology was that no definite results could be achieved due to the low mobility of NPs in the agarose matrix. A possibility to circumvent this low mobility is to switch to a liquid separation medium. Le Saux et al. [112], Ibrahim et al. [113] and Liu et al. [114] have shown that capillary electrophoresis might be a suitable alternative to separate and/or determine properties of larger analytes.

In addition to the previous mentioned methods several other methods deserve to be mentioned. With isothermal titration calorimetry Huang et al. [92] were able to study the interaction between NPs and adsorbed proteins. The same group also used circular dichroism spectroscopy (CD) to analyze the structure of BSA adsorbed to the surface of Au NPs. By measuring bound an unbound BSA they determined that the secondary structure of BSA adsorbed to the NP remained intact. Tunable nanopore resistive pulse sensing is an interesting new technique for measuring NP size distributions. NPs pass one by one through a nanopore inducing a change in current, and by tuning the size of the nanopore, Pal et al. have shown that accurate size distributions of nanoparticles could be determined [74]. Taylor dispersion analysis is also an alternative to traditional characterization techniques. Oukacine et al. [115], Le Saux et al. [112] and others [116] have shown that Taylor dispersion, although much less sensitive to polydispersity than e.g. DLS, is advantageous in certain cases and estimates particle size accurately.

The most common methods used to measure the concentration of NPs, as well as dissolution ratios, are inductively coupled plasmaoptical emission spectroscopy (ICP-OES), and mass spectrometry (ICP-MS). ICP is typically rapid, high-throughput, quantitative and extremely sensitive [117]. In this respect, ICP spectroscopies have been utilized to quantify the total content and dissolution rate of a wide range of plasmonic NPs, as shown in Table 2. The potential of ICP-MS in single particle mode has been explored as a technique to simultaneously determine size and ultra-trace concentration of NPs in suspension. If a sufficiently dilute suspension of NPs is nebulized into the plasma without previous digestion, a burst of ions is generated when each discrete particle is vaporized, atomized, and ionized. The ions of the element of interest are subsequently counted with a very high frequency, similar to the time scale of a particle event [118]. Particle aggregation can also be detected by monitoring the increase in signal intensity [81]. By collecting a large number of data points, particle size distributions can also be determined [119].

For determining changes in NP surface charge, Laser Doppler Electrophoresis and similar techniques have proven to be effective methods. Many groups have shown that zeta potential analysis is a useful complementary method for measuring not only the efficiency of particle functionalization, but also protein adsorption onto NP surfaces $[58,75,91]$.

\section{Conclusion and outlook}

Understanding the behavior of NPs in physiological fluids is essential in order to study their cellular uptake, intracellular trafficking or fate. Extensive research in the bio-nano field has been dedicated to NP synthesis, surface derivatization and possible cellular reactions. However, in order to translate nanomedicine from 
bench to bedside and to evaluate possible risks, a comprehensive characterization of the particles is needed not only after synthesis, but in the respective physiological fluid that the NPs are going to encounter. Since plasmonic NPs are excellent probes for many analytical techniques that rely on light scattering and absorption, research is often carried out with Au or Ag NPs. In this review, we have presented different methods that are nowadays used for the detection and quantification of plasmonic NPs in physiological fluids. In order to understand NP behavior in physiological environments, it is not enough to only supply robust and universal characterization methods but also to be aware of their limitations, and apply, whenever possible, more than one technique [41].

Looking forward, it is apparent that the field merits further investigation. It has to be noted that the majority of published studies are performed with NPs incubated in serum completed cell culture media. However, NPs for biomedical applications will be systemically injected, ingested or inhaled. Therefore, a particular emphasis on more realistic physiological fluids such as blood, mucus etc. should be given in future studies.

\section{Acknowledgements}

Financial support from the Swiss National Science Foundation (Grant \# PP00P2126483/1), the Adolphe Merkle Foundation and the Swiss National Science Foundation through the National Cen3 tre of Competence in Research Bio-Inspired Materials is gratefully - acknowledged. L.R.-L. acknowledges the financial support from the L'Oreal Switzerland and UNESCO's fellowship program "For Women in Science 2013".

\section{References}

[1] M.R. Gwinn, V. Vallyathan, Environ. Health Perspect. (2006),

[2] The Nanotech Report, 4th ed., Lux Research, 2012.

[3] H.H. Fenniri, Int. J. Nanomed. 1 (2005) 225.

[4] S. Smita, S.K. Gupta, A. Bartonova, M. Dusinska, A.C. Gutleb, Q. Rahman, Environ. Health 11 (Suppl. 1) (2011) S13.

[5] G. Oberdörster, A. Maynard, K. Donaldson, V. Castranova, J. Fitzpatrick, K. Ausman, J. Carter, B. Karn, W. Kreyling, D. Lai, S. Olin, N. Monteiro-Riviere, D. Warheit, H. Yang, Part. Fibre Toxicol. 2 (2005) 8

[6] A.-H. Lu, E.L. Salabas, F. Schüth, Angew. Chem. Int. Ed. 46 (2007) 1222.

[7] P. Senthil Kumar, A. Pastoriza-Santos, B. Rodríguez-González, F. Javier García de Abajo, L.M. Liz-Marzán, High-yield synthesis and optical response of gold nanostars, Nanotechnology 19 (2008) 015606.

[8] F. Shieh, A.E. Saunders, B.A. Korgel, J. Phys. Chem. B 109 (2005) 8538.

[9] E.C. Cho, Q. Zhang, Y. Xia, Nat. Nanotechnol. 6 (2011) 385.

[10] A. Petri-Fink, M. Chastellain, L. Juillerat-Jeanneret, A. Ferrari, H. Hofmann, Biomaterials 26 (2005) 2685.

11] J. Jiang, G. Oberdörster, P. Biswas, J. Nanopart. Res. 11 (2008) 77.

[12] L.K. Limbach, Y. Li, R.N. Grass, T.J. Brunner, M.A. Hintermann, M. Muller, D. Gunther, W.J. Stark, Environ. Sci. Technol. 39 (2005) 9370.

[13] R.C. Murdock, L. Braydich-Stolle, A.M. Schrand, J.J. Schlager, S.M. Hussain, Toxicol. Sci. 101 (2008) 239.

[14] J.S. Gebauer, M. Malissek, S. Simon, S.K. Knauer, M. Maskos, R.H. Stauber, W. Peukert, L. Treuel, Langmuir 28 (2012) 9673.

[15] A.E. Nel, L. Mädler, D. Velegol, T. Xia, E.M.V. Hoek, P. Somasundaran, F. Klaessig, V. Castranova, M. Thompson, Nature 8 (2009) 543.

[16] A.P. Corfield, BBA - Gen. Subj. 1850 (2015) 236.

[17] L.M. Lichtenberger, Annu. Rev. Physiol. 57 (1994) 565.

[18] J. Grießinger, S. Dünnhaupt, B. Cattoz, P. Griffiths, S. Oh, S.B.I. Gómez, M. Wilcox, J. Pearson, M. Gumbleton, A. Bernkop-Schnürch, Eur. J. Pharm. Biopharm. (2015) 1.

[19] I.P. de Sousa, B. Cattoz, M.D. Wilcox, P.C. Griffiths, R. Dalgliesh, S. Rogers, A. Bernkop-Schnürch, Eur. J. Pharm. Biopharm. (2015), http://dx.doi.org/10. 1016/j.ejpb.2015.01.008

[20] J. Kirch, A. Schneider, B. Abou, A. Hopf, U.F. Schaefer, M. Schneider, C. Schall, C. Wagner, C.-M. Lehr, Proc. Natl. Acad. Sci. U. S. A. 109 (2012) 18355.

[21] S.K. Lai, Y.-Y. Wang, D. Wirtz, J. Hanes, Adv. Drug Deliv. Rev. 61 (2009) 86.

[22] F. Laffleur, F. Hintzen, G. Shahnaz, D. Rahmat, K. Leithner, A. BernkopSchnürch, Nanomedicine (Lond) 9 (2014) 387.

[23] O. Lieleg, I. Vladescu, K. Ribbeck, Biophys. J. 98 (2010) 1782.

[24] F. Green, P. Gehr, M. Lee, S. Schurch, In: P. Gehr, J. Heyder (Eds.), ParticleLung Interactions (Lung Biology in Health and Disease), first ed., Informa Healthcare, n.d., pp. 533-576.
[25] D.O.D. Raemy, L.K.L. Limbach, B.B. Rothen-Rutishauser, R.N.R. Grass, P.P. Gehr, K.K. Birbaum, C.C. Brandenberger, D.D. Günther, W.J.W. Stark, Eur. J. Pharm. Biopharm. 77 (2011) 8

[26] M.T. Lopez-Vidriero, Respiration 55 (Suppl. 1) (1988) 28

[27] P.F. Bove, B.R. Grubb, S.F. Okada, C.M.P. Ribeiro, T.D. Rogers, S.H. Randell, W.K. O’Neal, R.C. Boucher, J. Biol. Chem. 285 (2010) 34939.

[28] L.K. Braydich-Stolle, E.K. Breitner, K.K. Comfort, J.J. Schlager, S.M. Hussain, Langmuir 30 (2014) 15309.

[29] J.W. Nichols, Y.H. Bae, Nano Today 7 (2012) 606.

[30] M.J.D. Clift, J.-F. Dechézelles, B. Rothen-Rutishauser, A. Petri-Fink, Front. Chem. 3 (2015).

[31] H. Gao, Q. He, Expert Opin. Drug Deliv. 11 (3) (2014) 409-420.

[32] M.J. Hajipour, S. Laurent, A. Aghaie, F. Rezaee, M. Mahmoudi, Biomater. Sci. 2 (2014) 1210 .

[33] J.B. Hall, M.A. Dobrovolskaia, A.K. Patri, S.E. McNeil, Nanomedicine (Lond) 2 (2007) 789.

[34] M. Lundqvist, J. Stigler, G. Elia, I. Lynch, T. Cedervall, K.A. Dawson, Proc. Natl. Acad. Sci. U. S. A. 105 (2008) 14265.

[35] R.G. Digigow, J.-F. Dechézelles, J. Kaufmann, D. Vanhecke, H.F. Knapp, M. Lattuada, B. Rothen, A.S. Fink, Lab. Chip 14 (2014) 2276.

[36] U. Sakulkhu, L. Maurizi, M. Mahmoudi, M. Motazacker, M. Vries, A. Gramoun, M.-G.O. Beuzelin, J.-P. Vallee, F. Rezaee, H. Hofmann, Nanoscale 6 (2014) 11439.

[37] V. Hirsch, C. Kinnear, M. Moniatte, B. Rothen-Rutishauser, M.J.D. Clift, A. PetriFink, Nanoscale 5 (2013) 3723.

[38] S.N. Thomas, E. Vokali, A.W. Lund, J.A. Hubbell, M.A. Swartz, Biomaterials 35 (2014) 814.

[39] F. Blank, P.A. Stumbles, E. Seydoux, P.G. Holt, A. Petri-Fink, B. RothenRutishauser, D.H. Strickland, C. Von Garnier, Am. J. Respir. Cell Mol. Biol. 49 (2013) 67.

[40] S.S. Dukhin, M.E. Labib, Adv. Colloid Interface Sci. 199-200 (2013) 23.

[41] T.L. Moore, L. Rodriguez-Lorenzo, V. Hirsch, S. Balog, D. Urban, C. Jud, B. Rothen-Ruthishauser, M. Lattuada, A. Petri-Fink, Chem. Soc. Rev. (2015); (Advance Article DOI: 10.1039/C4CS00487F, Review Article First published online: 09.06.15)

[42] T. Cedervall, I. Lynch, S. Lindman, T. Berggård, E. Thulin, H. Nilsson, K.A. Dawson, S. Linse, Proc. Natl. Acad. Sci. U. S. A. 104 (2007) 2050.

[43] L. Treuel, G.U. Nienhaus, Biophys. Rev. 4 (2012) 137.

[44] K. Rausch, A. Reuter, K. Fischer, M. Schmidt, Biomacromolecules 11 (2010) 2836.

[45] P. Meakin, J. Colloid Interface Sci. 102 (1984) 491.

[46] P. Wick, P. Manser, L.K. Limbach, U. Dettlaffweglikowska, F. Krumeich, S. Roth, W. Stark, A. Bruinink, Toxicol. Lett. 168 (2007) 121.

[47] T.S. Peretyazhko, Q. Zhang, V.L. Colvin, Environ. Sci. Technol. 48 (2014) 11954.

[48] A.-K. Ostermeyer, C. Kostigen Mumuper, L. Semprini, T. Radniecki, Environ. Sci. Technol. 47 (2013) 14403.

[49] R. Ma, C. Levard, S.M. Marinakos, Y. Cheng, J. Liu, F.M. Michel, G.E. Brown, G.V. Lowry, Environ. Sci. Technol. 46 (2012) 752

[50] T.A. Larson, P.P. Joshi, K. Sokolov, ACS Nano 6 (2012) 9182.

[51] G. Zhang, Z. Yang, W. Lu, R. Zhang, Q. Huang, M. Tian, L. Li, D. Liang, C. Li, Biomaterials 30 (2009) 1928.

[52] K.C. Honeychurch, Nanosensors for Chemical and Biological Applications, Elsevier, 2014.

[53] L.M. Liz-Marzán, Langmuir 22 (2006) 32.

[54] K.L. Kelly, E. Coronado, L.L. Zhao, G.C. Schatz, J. Phys. Chem. B 107 (2003) 668.

[55] X. Huang, S. Neretina, M.A. El-Sayed, Adv. Mater. 21 (2009) 4880.

[56] M.S. Khan, G.D. Vishakante, H. Siddaramaiah, Adv. Colloid Interface Sci. 199-200 (2013) 44

[57] A. Albanese, W.C.W. Chan, ACS Nano 5 (2011) 5478.

[58] S. Balog, L. Rodriguez-Lorenzo, C.A. Monnier, M. Obiols-Rabasa, B. RothenRutishauser, P. Schurtenberger, A. Petri-Fink, Nanoscale 7 (2015) 5991.

[59] E. Casals, T. Pfaller, A. Duschl, G.J. Oostingh, V. Puntes, ACS Nano 4 (2010) 3623.

[60] E. Casals, T. Pfaller, A. Duschl, G.J. Oostingh, V.F. Puntes, Small 7 (2011) 3479.

[61] S.H.D.P. Lacerda, J.J. Park, C. Meuse, D. Pristinski, M.L. Becker, A. Karim, J.F. Douglas, ACS Nano 4 (2010) 365

[62] S. Dominguez-Medina, J. Blankenburg, J. Olson, C.F. Landes, S. Link, ACS Sustain. Chem. Eng. (2013), 130415083117001.

[63] J. Fatisson, I.R. Quevedo, K.J. Wilkinson, N. Tufenkji, Colloids Surf. B: Biointerfaces 91 (2012) 198.

[64] D. Hühn, K. Kantner C. Geidel, S. Brandholt, I. De Cock, S.J.H. Soenen, P. Rivera Gil, J.-M. Montenegro, K. Braeckmans, K. Müllen, G.U. Nienhaus, M. Klapper, W.J. Parak, ACS Nano 7 (2013) 3253.

[65] S. Kittler, C. Greulich, J.S. Gebauer, J. Diendorf, L. Treuel, L. Ruiz, J.M. GonzalezCalbet, M. Vallet-Regi, R. Zellner, M. Köller, M. Epple, J. Mater. Chem. 20 (2010) 512.

[66] A. Lankoff, W.J. Sandberg, A. Wegierek-Ciuk, H. Lisowska, M. Refsnes, B. Sartowska, P.E. Schwarze, S. Meczynska-Wielgosz, M. Wojewodzka, M. Kruszewski, Toxicol. Lett. 208 (2012) 197.

[67] L. Li, M.L. Fernández-Cruz, M. Connolly, M. Schuster, J.M. Navas, J. Nanopart. Res. 17 (2015) 38.

[68] H. Liu, N. Pierre-Pierre, Q. Huo, Gold Bull. 45 (2012) 187.

[69] R.I. MacCuspie, A.J. Allen, V.A. Hackley, Nanotoxicology 5 (2011) 140.

[70] D. Mahl, C. Greulich, W. Meyer-Zaika, M. Köller, M. Epple, J. Mater. Chem. 20 (2010) 6176. 
[71] I. Montes-Burgos, D. Walczyk, P. Hole, J. Smith, I. Lynch, K. Dawson, J. Nanopart. Res. 12 (2009) 47.

[72] D.F. Moyano, K. Saha, G. Prakash, B. Yan, H. Kong, M. Yazdani, V.M. Rotello, ACS Nano 8 (2014) 6748

[73] D. Mukherjee, B.F. Leo, S.G. Royce, A.E. Porter, M.P. Ryan, S. Schwander, K.F. Chung, T.D. Tetley, J. Zhang, P.G. Georgopoulos, J. Nanopart. Res. 16 (2014) 2616.

[74] A.K. Pal, I. Aalaei, S. Gadde, P. Gaines, D. Schmidt, P. Demokritou, D. Bello, ACS Nano 8 (2014) 9003.

[75] I.A. Pyshnaya, K.V. Razum, J.E. Poletaeva, D.V. Pyshnyi, M.A. Zenkova, E.I Ryabchikova, BioMed Res. Int. 2014 (2014) 1.

[76] M.G. Soliman, B. Pelaz, W.J. Parak, P. del Pino, Chem. Mater. 27 (2015) 990

[77] V. Hirsch, C. Kinnear, L. Rodriguez-Lorenzo, C.A. Monnier, B. RothenRutishauser, S. Balog, A. Petri-Fink, Nanoscale 6 (2014) 7325.

[78] L. Rodriguez-Lorenzo, B. Rothen-Rutishauser, A. Petri-Fink, S. Balog, Part. Part. Syst. Charact. 32 (2014) 321.

[79] S. Balog, L. Rodriguez-Lorenzo, C.A. Monnier, B. Michen, M. Obiols-Rabasa, L. Casal-Dujat, B. Rothen-Rutishauser, A. Petri-Fink, P. Schurtenberger, J. Phys. Chem. C 118 (2014) 17968.

[80] D. Aili, P. Gryko, B. Sepúlveda, J.A.G. Dick, N. Kirby, R. Heenan, L. Baltzer, B. Liedberg, M.P. Ryan, M.M. Stevens, Nano Lett. 11 (2011) 5564.

[81] S.V. Jenkins, H. Qu, T. Mudalige, T.M. Ingle, R. Wang, F. Wang, P.C. Howard, J. Chen, Y. Zhang, Biomaterials 51 (2015) 226.

[82] J.M. Zook, V. Rastogi, R.I. MacCuspie, A.M. Keene, J. Fagan, ACS Nano 5 (2011) 8070.

[83] A.R. Badireddy, M.R. Wiesner, J. Liu, Environ. Sci. Technol. (2012), 120904104842003

[84] M. Hu, C. Novo, A. Funston, H. Wang, H. Staleva, S. Zou, P. Mulvaney, Y. Xia, G.V. Hartland, J. Mater. Chem. 18 (2008) 1949.

[85] X. Huang, I.H. El-Sayed, W. Qian, M.A. El-Sayed, J. Am. Chem. Soc. 128 (2006) 2115.

[86] S. Leclerc, K.J. Wilkinson, Environ. Sci. Technol. 48 (2014) 358.

[87] M. Mortimer, A. Gogos, N. Bartolomé, A. Kahru, T.D. Bucheli, V.I. Slaveykova, Environ. Sci. Technol. 48 (2014) 8760.

[88] C. Rosman, S. Pierrat, A. Henkel, M. Tarantola, D. Schneider, E. Sunnick, A. Janshoff, C. Sönnichsen, Small 8 (2012) 3683.

[89] B.M. Stacy, K.K. Comfort, D.A. Comfort, S.M. Hussain, Plasmonics 8 (2013) 1235.

[90] N. Hondow, R. Brydson, P. Wang, M.D. Holton, M.R. Brown, P. Rees, H.D. Summers, A. Brown, J. Nanopart. Res. 14 (2012) 977.

91] S. Zhang, Y. Moustafa, Q. Huo, ACS Appl. Mater. Interfaces 6 (2014) 21184.

[92] R. Huang, R.P. Carney, K. Ikuma, F. Stellacci, B.L.T. Lau, ACS Nano 8 (2014) 5402.
[93] P. Maffre, K. Nienhaus, F. Amin, W.J. Parak, G.U. Nienhaus, Beilstein J. Nanotechnol. 2 (2011) 374.

[94] M. Chanana, P. RiveraGil, M.A. Correa-Duarte, L.M. Liz-Marzán, W.J. Parak, Angew. Chem. Int. Ed. 52 (2013) 4179.

[95] I. García, A. Sánchez-Iglesias, M. Henriksen-Lacey, M. Grzelczak, S. Penadés, L.M. Liz-Marzán, J. Am. Chem. Soc. 137 (2015) 3686.

[96] R.I. MacCuspie, K. Rogers, M. Patra, Z. Suo, A.J. Allen, M.N. Martin, V.A. Hackley, J. Environ. Monit. 13 (2011) 1212

[97] J.C.Y. Kah, C. Grabinski, E. Untener, C. Garrett, J. Chen, D. Zhu, S.M. Hussain, K. Hamad-Schifferli, ACS Nano 8 (2014) 4608.

[98] M. Mahmoudi, M.A. Shokrgozar, S. Bonakdar, M.K. Moghadam, S. Laurent, J. Iran. Chem. Soc. 8 (2011) 944.

[99] M. Tebbe, C. Kuttner, M. Männel, A. Fery, M. Chanana, ACS Appl. Mater. Interfaces 7 (2015) 5984.

100] C. Fu, H. Yang M. Wang. H. Xiong, S. Yu, Chem. Commun. 51 (2015) 3634.

[101] A. Vanderkooy, Y. Chen, F. Gonzaga, M.A. Brook, ACS Appl. Mater. Interfaces 3 (2011) 3942.

[102] L. Rodriguez-Lorenzo, K. Fytianos, F. Blank, C. Von Garnier, B. Rothen Rutishauser, A. Petri-Fink, Small 10 (2014) 1341.

[103] Y. Li, C. Jing, L. Zhang, Y.-T. Long, Chem. Soc. Rev. 41 (2012) 632.

[104] P. Alivisatos, Nat. Biotechnol. 22 (2003) 47.

[105] J. Aaron, K. Travis, N. Harrison, K. Sokolov, Nano Lett. 9 (2009) 3612.

[106] S. Schultz, D.R. Smith, J.J. Mock, D.A. Schultz, Proc. Natl. Acad. Sci. U. S. A. 97 (2000) 996

[107] M. Mahmood, Y. Xu, V. Dantuluri, T. Mustafa, Y. Zhang, A. Karmakar, D. Casciano, S. Ali, A. Biris, Nanotechnology 24 (2013) 045102.

[108] B. Michen, C. Geers, D. Vanhecke, C. Endes, B. Rothen-Ruthishauser, S. Balog, A Petri-Fink, Nat. Sci. Rep. 5 (2015) 9793, http://dx.doi.org/10.1038/srep09793

109] P.H. Brown, P. Schuck, Biophys. J. 90 (2006) 4651.

[110] J. Lebowitz, M.S. Lewis, P. Schuck, Protein Sci. 11 (2009) 2067.

[111] J. Liu, J.D. Andya, S.J. Shire, AAPS J. 8 (2005) E580.

112] T. Le Saux, H. Cottet, Anal. Chem. 80 (2008) 1829.

[113] A. Ibrahim, H. Ohshima, S.A. Allison, H. Cottet, J. Chromatogr. A 1247 (2012) 154

[114] L. Liu, B. He, Q. Liu, Z. Yun, X. Yan, Y. Long, G. Jiang, Angew. Chem. 126 (2014) 14704.

[115] F. Oukacine, S. Bernard, I. Bobe, H. Cottet, J. Control. Release 196 (2014) 139.

116] B.M. Belongia, J.C. Baygents, J. Colloid Interface Sci. 195 (1996) 19.

117] H.E. Taylor, Inductively Coupled Plasma-Mass Spectrometry, Academic Press, 2001.

[118] J. Tuoriniemi, G. Cornelis, M. Hassellov, Anal. Chem. 84 (2012) 3965.

[119] E.P. Gray, J.G. Coleman, A.J. Bednar, A.J. Kennedy, J.F. Ranville, C.P. Higgins, Environ. Sci. Technol. 47 (2013) 14315. 